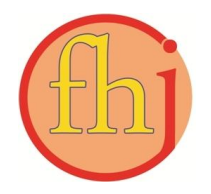

Faletehan Health Journal, 7 (1) (2020) 68-74

www. journal.Ippm-stikesfa.ac.id/ojs/index.php/FHJ

ISSN 2088-673X | e-ISSN 2597-8667

\title{
Determinan Pemanfaatan Jamban Keluarga pada Keluarga
}

\author{
Puji Eka M athofani ${ }^{1}$, Annissa $^{1 *}$, Rika Prastiwi M etalia $^{1}$ \\ ${ }^{1}$ Program Studi Kesehatan M asyarakat, Universitas Faletehan \\ *Corresponding Author: annissa1206@gmail.com
}

\begin{abstract}
Abstrak
Jamban merupakan salah satu kebutuhan pokok manusia, diharapkan tiap individu untuk memanfaatkan fasilitas jamban untuk buang air besar. Berdasarkan data dari Puskesmas DTP Cipanas sebanyak 1.502 jiwa yang akses jamban dari 4.237 jiwa. Penelitian ini bertujuan untuk mengetahui Faktor - faktor yang berhubungan dengan pemanfaatan Jamban keluarga di Desa Cipanas Wilayah Kerja Puskesmas Rawat Inap Cipanas Kecamatan Cipanas Kabupaten Lebak Tahun 2019. Desain Penelitian bersifat cross sectional. Populasi penelitian adalah seluruh kepala keluarga di Desa Cipanas yang berjumlah 1.158 kepala keluarga dengan jumlah sampel sebanyak 101 kepala keluarga, dimana sampel diambil dengan metode simple random sampling. Pengumpulan data primer menggunakan kuisioner dengan cara wawancara, sedangkan data sekunder diperoleh dari Puskesmas Rawat Inap Cipanas. Hasil analisa menunjukan dari 101 responden sebanyak 45.4\% tidak memanfaatkan jamban, 82.2\% memiliki pendapatan tinggi, 58.4\% memiliki sikap yang kurang baik, $62.4 \%$ tidak memiliki jamban, $71.3 \%$ adanya peran petugas kesehatan, dan $61.4 \%$ adanya peran tokoh masyarakat. Uji hubungan data penelitian menunjukkan bahwa terdapat hubungan yang bermakna antara sikap, kepemilikan jamban, peran petugas kesehatan ( $P v=0.000)$, peran tokoh masyarakat $(P v=0,005)$ dengan pemanfaatan jamban keluarga. Saran untuk penelitian ini adalah perlunya peningkatan pengetahuan dan kesadaran kepala keluarga dalam pemanfaatan jamban keluarga.
\end{abstract}

Kata Kunci: Jamban keluarga, Peran petugas kesehatan, Pendapatan, Sikap

\section{Determinants of Family Latrine Use in Families}

\begin{abstract}
Latrines are one of the basic human needs, it is expected that each individual uses the toilet facilities for defecation. Based on data from the Cipanas Inpatient Health Center as many as 1,502 people have access to 4,237 latrines. This study aims to determine the factors associated with the use of family latrines in the Cipanas Village Cipanas Inpatient Health Work Area Cipanas District Lebak Regency in 2019. The research design is cross-sectional. The study population was all family heads in Cipanas Village, amounting to 1.158 families with a sample of 101 households, where the sample was taken by a simple random sampling method. Primary data collection using questionnaires by interview, while secondary data were obtained from the Cipanas Health Center. Analysis results showed that out of 101 respondents $45.4 \%$ did not use latrines, $82.2 \%$ had high incomes, $58.4 \%$ had poor attitudes, $62.4 \%$ did not have latrines, $71.3 \%$ had the role of health workers, and $61.4 \%$ had community leaders. The correlation analysis shows that there is a significant relationship between attitudes, latrine ownership, the role of health workers $(P v=0.000)$, the role of community leaders ( $P v=0.005)$ and the use of family latrines. Suggestions for this research are the need to increase the knowledge and awareness of family heads in the use of family latrines.

Keywords: Family latrines, Income, Role of health supervisors, Attitude
\end{abstract}


Faletehan Health Journal, 7 (1) (2020) 68-74

www. journal.Ippm-stikesfa.ac.id/ojs/index.php/FHJ

ISSN 2088-673X | 2597-8667

\section{Pendahuluan}

Program Indonesia Sehat telah disepakati adanya 12 indikator utama untuk penanda status kesehatan sebuah keluarga. Salah satu indikator utama tersebut adalah Keluarga mempunyai akses sanitasi yang layak atau menggunakan jamban sehat (Moeloek, 2016). Sanitasi berhubungan dengan kesehatan lingkungan yang mempengaruhi derajat kesehatan masyarakat. Buruknya kondisi sanitasi akan berdampak negatif di banyak aspek kehidupan, mulai dari turunnya kualitas lingkungan hidup masyarakat, tercemarnya sumber air minum bagi masyarakat, meningkatnya jumlah kejadian diare dan munculnya beberapa penyakit (Kemenkes RI, 2017).

Betapa pentingnya akses sanitasi sehingga tinjauan kesehatan membuktikan bahwa sanitasi yang tidak layak menjadi faktor penyebab penularan berbagai penyakit seperti diare, kolera, disentri, hepatitis A, tifus, polio dan terhambatnya pertumbuhan pada balita (Moeloek, 2016). Berdasarkan data dan informasi Dirjen P2P tahun 2016 bahwa penemuan kasus diare yang ditangani masih tinggi yaitu sebesar $36,9 \%$, jauh dari target yang diinginkan yaitu $<1 \%$ (Kemenkes RI, 2018). Salah satu upaya untuk mencegah berkembangnya penyakit dan menjaga lingkungan menjadi bersih dan sehat dengan cara membangun jamban di setiap rumah. Karena jamban merupakan salah satu kebutuhan pokok manusia. Maka diharapkan tiap individu untuk memanfaatkan fasilitas jamban untuk buang air besar. Penggunaan jamban akan bermanfaat untuk menjaga lingkungan tetap bersih, nyaman dan tidak berbau (Alamsyah dan Muliawati, 2013).

Berdasarkan data dari profil kesehatan Propinsi Banten pada tahun 2017, bahwa persentase rumah tangga yang memiliki akses terhadap sanitasi layak tahun 2015 sebesar 67,04\%, tahun $201673,42 \%$, dan tahun 2017 sebesar $71,68 \%$. Walaupun terjadi peningkatan setiap tahunnya, namun belum mencapai target yaitu sebesar 100\% (Dinas Kesehatan Propinsi Banten, 2017). Berdasarkan sumber Data Seksi Kesehatan Lingkungan Dinas Kesehatan Kabupaten Lebak, diketahui cakupan akses jamban sehat hanya mengalami kenaikan sebesar $1.85 \%$ dari 68,47\% pada tahun 2017 menjadi $70,32 \%$ dengan target yang masih sama yaitu 100 \% (Dinas Kesehatan Kabupaten Lebak, 2018).
Berdasarkan data yang diperoleh dari Puskesmas Rawat Inap Cipanas Kecamatan Cipanas Kabupaten Lebak tahun 2018 jumlah jiwa yang akses terhadap jamban di 14 desa pada Kecamatan Cipanas sebanyak 19.533 jiwa $(37,76 \%)$ dari total jiwa keseluruhan berjumlah 49.557 jiwa, dan diantara desa yang ada di wilayah kerja Puskesmas Rawat Inap Cipanas, Desa Cipanas menjadi urutan yang paling rendah akses terhadap jamban dengan jumlah jiwa yang akses terhadap jamban sebanyak 1.502 jiwa $(35,45 \%)$ dari jumlah keseluruhan penduduk di desa Cipanas 4.237 jiwa, sedangkan jumlah Kepala Keluarga (KK) yang memiliki jamban sebanyak 339 dari total keseluruhan 1.140 KK. Berdasarkan dari penjelasan latar belakang diatas, maka penelitian ini bertujuan untuk mengetahui faktor-faktor yang berhubungan dengan pemanfaatan jamban keluarga di Desa Cipanas Kecamatan Cipanas Kabupaten Lebak.

\section{Metode Penelitian}

Penelitian ini menggunakan metode kuantitatif dengan desain cross-sectional. Penelitian ini dilakukan di Desa Cipanas Kabupaten Lebak, pada bulan Maret - Agustus 2019. Populasi penelitian ini adalah kepala rumah tangga sebanyak 1.158 orang. Perhitungan besar sampel yang digunakan adalah uji hipotesis untuk dua proporsi populasi. Berdasarkan hasil perhitungan diperoleh jumlah sampel minimal sebanyak 101 responden, tehnik pengambilan sampel menggunakan simple random sampling, dimana sampel dibagi berdasarkan RW kemudian diperoleh proporsi sesuai perhitungan dan kemudian dari setiap RW diacak untuk mendapatkan sampel per KK. Pada penelitian pengumpulan data primer dilakukan dengan wawancara terhadap responden dan pengamatan dengan instrumen penelitian berupa kuisioner. Pengumpulan data sekunder dilakukan dengan melihat data dari Puskesmas Cipanas. Analisa data dilakukan secara univariat dan bivariat. Analisa univariat dilakukan untuk memperoleh gambaran data mengenai distribusi frekuensi dan proporsi tiap variabel dalam penelitian. Analisa bivariat dilakukan untuk mengetahui apakah ada hubungan yang signifikan antara variabel independen dan dependen dengan menggunakan Uji Kai Kuadrat (Chi Square Test), (Nilai $\mathrm{p} \leq 0,05$ ). Hasil dan Pembahasan 


\section{Gambaran Pemanfaatan Jamban Keluarga}

Hasil penelitian pada tabel 1 menunjukkan sebanyak $45,4 \%$ responden yang tidak memanfaatkan jamban keluarga, 17,8\% responden yang memiliki pendapatan rendah, sebanyak $58,4 \%$ responden yang memiliki sikap kurang baik, sebanyak $62,4 \%$ responden yang tidak memiliki jamban, sebanyak $28,7 \%$ responden yang menyatakan peran petugas kesehatan tidak mendukung, sebanyak 38,6 \% yang menyatakan peran tokoh masyarakat tidak mendukung.

\section{Determinan Pemanfaatan Jamban Keluarga}

Berdasarkan tabel 2, dari 18 responden yang memiliki pendapatan rendah sebanyak $11(61,1 \%)$ responden yang tidak memanfaatkan jamban, sedangkan dari 83 responden yang memiliki pendapatan tinggi sebanyak $35(42,2 \%)$ yang tidak memanfaatkan jamban. Dari 59 responden yang memiliki sikap kurang baik sebanyak 42 $(71,2 \%)$ yang tidak memanfaatkan jamban, sedangkan dari 42 responden yang memiliki sikap baik sebanyak $4(9,5 \%)$ yang tidak memanfaatkan jamban. Dari 63 responden yang tidak memiliki jamban sebanyak $43(68,3 \%)$ responden tidak memanfaatkan jamban, sedangkan dari 38 responden yang memiliki jamban sebanyak 3 $(7,9 \%)$ responden tidak memanfaatkan jamban. Dari 29 responden yang menyatakan peran petugas kesehatan tidak mendukung sebanyak 20 (69\%) responden tidak memanfaatkan jamban sedangakan dari 72 responden yang menyatakan peran petugas kesehatan mendukung sebanyak 26 $(36,1 \%)$ responden tidak memanfaatkan jamban. Dari 39 responden yang menyatakan peran tokoh masyarakat tidak mendukung sebanyak 28 $(71,8 \%)$ responden yang tidak memanfaatkan jamban, sedangkan dari 62 responden yang menyatakan peran tokoh masyarakat mendukung sebanyak 18 (29\%)responden tidak memanfaatkan jamban.

\section{Tabel 1. Distribusi Frekuensi Variabel Pemanfaatan Jamban Keluarga, Pendapatan, Sikap, Kepemilikan Jamban, Peran Petugas Kesehatan dan Peran Tokoh Masyarakat $(\mathrm{n}=101)$}

\begin{tabular}{lcc}
\hline \multicolumn{1}{c}{ Variabel } & n & \% \\
\hline $\begin{array}{l}\text { Pemanfaatan Jamban } \\
\text { Keluarga } \\
\text { Tidak memanfaatkan }\end{array}$ & & \\
Memanfaatkan & 46 & 45,4 \\
\hline $\begin{array}{l}\text { Pendapatan } \\
\text { Rendah }\end{array}$ & 55 & 54,5 \\
Tinggi & 18 & 17,8 \\
\hline Sikap & 83 & 82,2 \\
Kurang Baik & & \\
Baik & 59 & 58,4 \\
\hline Kepemilikan Jamban & 42 & 41,6 \\
Tidak Memiliki & 63 & 62,4 \\
Memiliki & 38 & 37,6 \\
\hline $\begin{array}{l}\text { Peran Petugas } \\
\text { Kesehatan } \\
\text { Tidak mendukung }\end{array}$ & & \\
Mendukung & 29 & 28,7 \\
\hline $\begin{array}{l}\text { Peran Tokoh } \\
\text { Masyarakat }\end{array}$ & 72 & 71,3 \\
$\begin{array}{l}\text { Tidak Mendukung } \\
\text { Mendukung }\end{array}$ & & \\
\hline
\end{tabular}

Tabel 2. Determinan Pemanfaatan Jamban Keluarga

\begin{tabular}{|c|c|c|c|}
\hline \multirow{2}{*}{ Variabel } & \multicolumn{2}{|c|}{ Pemanfaatan Jamban Keluarga } & \multirow{2}{*}{ P Value } \\
\hline & Tidak Memanfaatkan (\%) & Memanfaatkan (\%) & \\
\hline \multicolumn{4}{|l|}{ Pendapatan } \\
\hline Rendah & $11(61.1)$ & $7(38.9)$ & 0.229 \\
\hline Tinggi & $35(42.2)$ & $48(57.8)$ & \\
\hline \multicolumn{4}{|l|}{ Sikap } \\
\hline Kurang Baik & $42(71.2)$ & $17(28.8)$ & 0,000 \\
\hline Baik & $4(9.5)$ & $38(90.5)$ & \\
\hline \multicolumn{4}{|l|}{ Kepemilikan Jamban } \\
\hline Tidak Memiliki & $43(68.3)$ & $20(31.7)$ & 0,000 \\
\hline Memiliki & $3(7.9)$ & $35(92.1)$ & \\
\hline \multicolumn{4}{|c|}{ Peran Petugas Kesehatan } \\
\hline Tidak Mendukung & $20(69)$ & $9(31)$ & 0,000 \\
\hline Mendukung & $26(36.1)$ & $46(63.9)$ & \\
\hline \multicolumn{4}{|c|}{ Peran tokoh masyarakat } \\
\hline Tidak Mendukung & $28(71.8)$ & $11(28.2)$ & 0,005 \\
\hline Mendukung & $18(29)$ & $44(71)$ & \\
\hline
\end{tabular}


Faletehan Health Journal, 7 (1) (2020) 68-74

www. journal.Ippm-stikesfa.ac.id/ojs/index.php/FHJ

ISSN 2088-673X | 2597-8667

Hasil analisis menggunakan uji chi-square diperoleh hubungan yang signifikan antara sikap (Nilai $\mathrm{p}=0.000$ ), Kepemilikan jamban (Nilai $\mathrm{p}=0.000$ ), Peran petugas kesehatan (Nilai $\mathrm{p}=0.000$ ), dan Peran tokoh masyarakat (Nilai $\mathrm{p}=0.005)$ dengan pemanfaatan jamban keluarga. Pendapatan (Nilai $\mathrm{p}=0.229$ ) secara statistik tidak ada hubungan yang signifikan dengan pemanfaatan jamban keluarga.

\section{Pendapatan}

Berdasarkan hasil penelitian tidak terdapat hubungan yang bermakna antara pendapatan dengan pemanfaatan jamban keluarga. Hal ini sejalan dengan hasil penelitian yang dilakukan oleh Paramitha R.D. dan Sulistyorini L (2015), tentang sikap kepala keluarga mempengaruhi rendahnya penggunaan jamban yang menunjukkan bahwa tidak terdapat hubungan antara pendapatan keluarga dengan pemanfaatan jamban sehat, dengan nilai pvalue $=0,923$. Menurut Notoatmodjo (2011), bahwa pendapatan keluarga menentukan ketersediaan fasilitas kesehatan yang baik. Semakin tinggi pendapatan keluarga, semakin baik fasilitas dan cara hidup mereka yang terjaga akan semakin baik.

Dari hasil penelitian ini dapat dilihat bahwa sebagian besar kepala keluarga di Desa Cipanas memiliki pendapatan tinggi karena pendapatan yang diperoleh diatas rata - rata yaitu Rp.1.000.000. Walaupun pendapatan yang dikategorikan tinggi tetapi mayoritas masyarakat bekerja sebagai buruh harian lepas dan adanya kesenjangan yang masih jauh dengan UMR di Kabupaten Lebak yaitu Rp. 2.500 .000 sesuai dengan SK Bupati Lebak.

Berdasarkan hasil penelitian, peneliti berpendapat bahwa pendapatan keluarga adalah sama, baik tinggi maupun rendah dan dalam pemanfaatan jamban sehat tidak hanya dipengaruhi secara finansial saja, kemungkinan juga faktor sosial budaya dan lingkungan sekitar tempat tinggal. Alasan lain yang menyebabkan masyarakat enggan menggunakan jamban karena masyarakat beranggapan pembangunan jamban membutuhkan biaya yang besar dan adanya lahan, sehingga masyarakat lebih memilih buang air besar di sungai. Selain itu pemahaman tentang sanitasi yang bukan merupakan kebutuhan pokok sangat mempengaruhi dalam hal pemanfaatan jamban sehingga tidak menutup kemungkinan masyarakat yang memiliki penghasilan tinggi pun tidak memiliki sarana jamban dirumah.

\section{Sikap}

Pada penelitian ini dari 59 responden dengan sikap kurang baik sebanyak 17 (28.8\%) responden yang memanfaatkan jamban keluarga dan dari 42 responden yang bersikap baik sebanyak 38 (90,5\%) responden yang memanfaatkan jamban keluarga. Hasil uji menunjukkan terdapat hubungan yang bermakna antara sikap dengan pemanfaatan jamban keluarga. Hal ini sejalan dengan hasil penelitian yang dilakukan oleh Kurniawati L.D dan Windraswara Rudatin (2017), tentang faktor-faktor yang berpengaruh terhadap perilaku kepala keluarga dalam pemanfaatan jamban sehat di Pemukiman Kampung Nelayan Tambaklorok Semarang, yang menunjukkan bahwa terdapat hubungan antara sikap dengan pemanfaatan jamban sehat dengan nilai pvalue $=0,008$. Faktor penentu sikap seseorang salah satunya adalah faktor komunikasi sosial.Informasi yang diterima individu tersebut dapat menyebabkan perubahan sikap pada diri individu tersebut. Positif atau negatif informasi dari proses komunikasi tersebut tergantung seberapa besar hubungan sosial dengan sekitarnya mampu mengarahkan individu tersebut bersikap dan bertindak sesuai dengan informasi yang diterimanya (Sunaryo, 2004).

Berdasarkan hasil penelitian, teori terkait dan penelitian terkait, maka peneliti berpendapat bahwa sebagian sikap kepala keluarga dalam pemanfaatan jamban sehat cukup baik. Sikap yang baik apabila didukung dengan sarana dan prasarana yang mendukung akan menghasilkan suatu tindakan, dalam hal ini adalah penggunaan jamban. Semakin baik sikap individu maka semakin baik individu tersebut memanfaatkan jamban sesuai dengan kegunaannya. Terdapat beberapa faktor yang dapat mempengaruhi pembentukan sikap antara lain: pengalaman pribadi, orang lain yang dianggap penting, dan pengaruh kebudayaan (Anggoro, 2014). Maka dari itu perlu adanya upaya peningkatan sikap ke arah yang benar. Dalam mengarahkan sikap yang benar, perlu dilakukan contoh bagaimana menggunakan jamban yang benar, sehingga masyarakat akan merespon dengan baik. Karena dari hasil penelitian sendiri masyarakat menyatakan bila tidak buang air besar dijamban 
dapat merugikan kesehatan tapi karena banyaknya faktor yang mempengaruhi seperti yang sudah disebutkan diatas maka pola untuk merubah dan mengarahkan sikap masyarakat untuk memanfaatkan jamban perlu upaya yang terus menerus harus dilakukan, hal ini dapat dimulai dari lingkup terkecil yaitu keluarga, kemudian dilanjutkan oleh pemerintah serta petugas kesehatan melalui program penyuluhan dengan melibatkan masyarakat sebagai objek sasaran sebuah program mulai dari penyusunan hingga pelaksanaan program.

\section{Kepemilikan Jamban}

Pada penelitian ini responden yang tidak memiliki jamban sebanyak $20 \quad(31,7 \%)$ yang memanfaatkan jamban keluarga, sedangkan dari 38 responden yang memiliki jamban sebanyak 35 $(92,1 \%)$ responden yang memanfaatkan jamban keluarga. Hasil uji menunjukkan terdapat hubungan yang bermakna antara kepemilikan jamban dengan pemanfaatan jamban keluarga.di Desa Cipanas Wilayah Kerja Puskesmas Rawat Inap Cipanas Tahun 2019, dan nilai OR (Odds Ratio $)=25,083$, artinya responden yang tidak memiliki jamban 25 kali lebih berisiko untuk tidak memanfaatkan jamban keluarga dibandingkan dengan responden yang memiliki jamban. Masyarakat yang tidak memiliki jamban keluarga, mereka menumpang ke saudara dan tetangga untuk Buang Air Besar (BAB) dan sebagian besar masyarakat yang tidak memiliki jamban menggunakan sungai, selokan dan kebun sebagai sarana untuk $\mathrm{BAB}$, karena di desa Cipanas ini hampir seluruh wilayah desa dikelilingi oleh sungai yang besar.

Terdapat banyak hal yang melatarbelakangi responden dalam memutuskan untuk memiliki jamban keluargai atau tidak. Sebagaian besar responden atau 70,26\% penduduk Desa Cipanas tidak memiliki jamban keluarga. Hal tersebut tentunya menjadi sesuatu yang penting untuk diperhatikan karena sangat berkaitan dengan kesehatan masyarakat di Desa Cipanas. Alasan sebagian besar responden tidak memiliki jamban adalah tidak memiliki cukup dana untuk membuat jamban pribadi atau jamban yang ideal di rumah mereka. Alasan lain yang kerap muncul adalah letak geografis tempat tinggal responden yang kurang memungkinkan untuk pembangunan jamban pribadi di setiap rumah mereka. Namun menurut Otayya (2012), alasan masyarakat yang belum memiliki jamban bukan semata-mata hanya karena faktor ekonomi, tetapi lebih kepada kurangnya kesadaran masyarakat tentang PHBS. Selain itu faktor lainya adalah ketergantungan masyarakat kepada bantuan pemerintah dalam hal pembangunan jamban. Hal tersebut tentunya akan lebih efektif apabila pemberian bantuan tersebut disertai dengan sosialisasi yang bersifat edukatif berkaitan dengan pemanfaatan jamban.

\section{Peran Petugas Kesehatan}

Pada penelitian ini dari 29 responden yang menyatakan peran petugas kesehatan tidak mendukung sebanyak $9 \quad(31 \%)$ responden memanfaatkan jamban keluarga, sedangkan dari 72 responden menyatakan peran petugas kesehatan mendukung sebanyak $46 \quad(63,9 \%)$ responden yang memanfaatkan jamban keluarga. Hasil uji hubungan yang bermakna antara peran petugas kesehatan dengan pemanfaatan jamban keluarga, dan nilai OR (Odds Ratio) $=3,932$, artinya, responden yang menyatakan peran petugas kesehatan tidak mendukung 3,9 kali lebih berisiko untuk tidak memanfaatkan jamban keluarga dibandingkan dengan responden yang menyatakan peran petugas kesehatan mendukung.

Hasil penelitian ini sejalan dengan hasil penelitian Pebriani (2012) tentang faktor yang berhubungan dengan pemanfaatan jamban, yaitu didapatkan hubungan yang bermakna antara peranan petugas kesehatan dengan pemanfatan jamban dengan nilai $p=0,005$, namun masih ada peran petugas kesehatan yang tidak mendukung karena ada beberapa responden yang tidak dilakukan kunjungan rumah oleh petugas kesehatan. Responden menyatakan bahwa mereka mendapatkan informasi tentang pemanfaatan jamban sehat dari penyuluhan ataupun promosi kesehatan yang dilakukan petugas sewaktu adanya kunjungan rumah yang dilakukan oleh petugas kesehatan. Namun petugas kadang-kadang tidak memperlihatkan selebaran atau leaflet tentang jamban dan manfaat dari pemanfaatan jamban sehat sehingga informasi yang diperoleh masih kurang jelas, karena mereka hanya mendengar ucapan yang disampaikan oleh petugas sehingga sering lupa apa yang telah disampaikan oleh petugas kesehatan tersebut. Progam Indonesia Sehat melalui pendekatan keluarga (PISPK) diharapkan dapat mendorong kepala keluarga untuk memiliki jamban sehat dan memanfaatan jamban sehat tersebut selain itu kegiatan 
Faletehan Health Journal, 7 (1) (2020) 68-74 www. journal.Ippm-stikesfa.ac.id/ojs/index.php/FHJ ISSN 2088-673X | 2597-8667

pemicuan yang dilakukan oleh sanitarian diharapkan dapat memicu rasa jijik untuk merubah perilaku buang air besar sembarangan dan lebih memanfaatkan jamban keluarga.

Petugas kesehatan merupakan salah satu pendorong masyarakat untuk memilikidan memanfaatkan jamban sehat (Pebriani, 2012). Petugas kesehatan merupakan orang yang cukup didengar nasehatnya oleh masyarakat. Nasehat yang diberikan berupa demi kesehatan kepala keluarga dan anggota keluarganya. Petugas kesehatan merupakan ujung tombak dalam mempromosikan dan memberikan penyuluhan tentang pentingnya memanfaatkan jamban sehat.

\section{Peran Tokoh Masyarakat}

Pada penelitian ini dari 39 responden yang menyatakan peran tokoh masyarakat tidak mendukung sebanyak $11(28,2 \%)$ responden yang memanfaatkan jamban keluarga, sedangkan dari 62 responden menyatakan peran tokoh masyarakat mendukung sebanyak 44 (71\%) responden yang memanfaatkan jamban keluarga. Hasil uji menunjukkan hubungan yang bermakna antara peran tokoh masyarakat dengan pemanfaatan jamban keluarga, dan nilai OR (Odds Ratio) $=$ 6,222 , artinya responden yang menyatakan peran tokoh masyarakat tidak mendukung 6 kali lebih berisiko untuk tidak memanfaatkan jamban keluarga dibandingkan dengan responden yang menyatakan peran tokoh masyarakat mendukung.

Penelitian ini tidak sejalan dengan hasil penelitian Kurniawati (2017), yang menunjukkan bahwa tidak terdapat hubungan antara dukungan tokoh masyarakat dengan pemanfaatan jamban sehat, dengan pvalue $=0,548$.

Menurut teori Snehandu B. Kar dalam Notoatmodjo (2007) yang mengungkapkan bahwa perilaku kesehatan bertitik tolak pada ada atau tidaknya dukungan sosial dari tokoh masyarakat, petugas kesehatan dan ada tidaknya informasi kesehatan, artinya masyarakat yang mendapat dukungan dari tokoh masyarakat berpeluang untuk memiliki perilaku kesehatan yang lebih baik dibandingkan dengan masyarakat yang tidak mendapat dukungan dari tokoh masyarakat dan petugas. Sebagian besar tokoh masyarakat mendukung terhadap pemanfaatan jamban oleh masyarakat walaupun masih ada yang tidak mendukung terhadap pemanfaatan jamban sehat.

Dukungan tokoh masyarakat dianggap penting oleh kepala keluarga karena setiap tindakan dan ucapan akan mendapat perhatian dan diikuti oleh kepala keluarga. Dukungan berupa bantuan dana pembuatan jamban dilingkungan tempat tinggal responden. Selain itu kaitannya dengan kendala lahan diharapkan adanya dukungan bantuan berupa pembuatan septic tank komunal. Sedangkan ada tokoh masyarakat yang tidak mendukung terhadap pemanfaatan jamban karena hal ini kaitannya dengan kesehatan maka hanya petugas kesehatan dari puskesmas saja yang bisa memberikan dorongan dan ajakan kepada masyarakat untuk memanfaatkan jamban keluarga.

\section{Simpulan}

Berdasarkan penelitian dapat disimpulkan bahwa determinan pemanfaatan jamban di Desa Cipanas Kabupaten Lebak adalah sikap, kepemilikan jamban, peran tenaga kesehatan, dan peran tokoh masyarakat. Sebagian besar masyarakat belum memiliki jamban dan belum memanfaatkannya.

\section{Referensi}

Alamsyah, D., R. Muliawati (2013). Pilar Dasar Ilmu Kesehatan Masyarakat.

Yogyakarta. Nuha Medika.

Anggoro, F.F. 2014.Analisis Faktor yang Berhubungan dengan PemanfaatanJamban di Kawasan Perkebunan Kopi. Skripsi. Universitas Jember, Jember.http://repository.unej.ac.id/handle/12 3456789/62067

Dinas Kesehatan Propinsi Banten, (2017). Profil Kesehatan Tahun 2017.

Dinas Kesehatan Kabupaten Lebak, (2018). Profil Kesehatan Tahun 2018.

Kemenkes RI, (2017). Program Indonesia Sehat Dengan Pendekatan Keluarga Artikel. http://www.depkes.go.id/article/view/170707 00004/program-indonesia-sehat-denganpendekatan-keluarga.html. Diakses tanggal 01 Maret 2019.

Kurniawati.L.D. (2017). Faktor-faktor yang berpengaruh terhadap perilakukepala keluarga dalam pemanfaatan jamban di Pemukiman KampungNelayan Tambaklorok Semarang Pada URL :http://journal.unnes.ac.id/sju/index.php/phpj (diakses pada 09 Februari 2019). 
Faletehan Health Journal, 7 (1) (2020) 68-74

www. journal.Ippm-stikesfa.ac.id/ojs/index.php/FHJ

ISSN 2088-673X | 2597-8667

Moeloek Nila Farid. (2016). Sambutan Menteri Kesehatan Republik IndonesiaPada Peringatan Hari Kesehatan Nasional 14 November 2016.

Notoatmodjo, S. (2011). Metode Penelitian Kesehatan. Jakarta. Rineka Cipta

Notoatmodjo. (2007). Promosi Kesehatan dan Ilmu Perilaku. Jakarta. Rineka Cipta

Otayya, G.Lian, 2012. Pengetahuan, Sikap dan Tindakan Masyarakat TerhadapPenggunaan Jamban Keluarga (Studi Kasus di Desa Ilomanga Kecamatan TabangoKAbupaten Gorontalo). IAIN Sultan Amai Gorontalo.
Paramitha R.D. dan Sulistyorini L, 2015.Sikap Kepala Keluarga Memengaruhi Rendahnya Penggunaan Jamban di Rw. 02 Desa Gempolklutuk Kecamatan Tarik Kabupaten Sidoarjo.Jurnal Kesehatan Lingkungan Vol. 8, No. 2 Juli 2015: 184-194.

Profil Puskesmas Rawat Inap Cipanas Kabupaten Lebak. (2018).

Sunaryo, (2004). Psikologi untuk keperawatan. Jakarta. Penerbit Buku Kedokteran EGC. 